\title{
Agronomic benefits of alfalfa mulch applied to organically managed spring wheat
}

\author{
M. J. Wiens ${ }^{1}$, M. H. Entz ${ }^{1,3}$, R. C. Martin², and A. M. Hammermeister ${ }^{2}$ \\ ${ }^{1}$ Department of Plant Science, University of Manitoba, Winnipeg, Manitoba, Canada, R3T 2N2; \\ ${ }^{2}$ Organic Agriculture Centre of Canada, Nova Scotia Agricultural College, P.O. Box 550, Truro, \\ Nova Scotia, Canada B2N 5E3. Received 4 April 2005, accepted 15 September 2005.
}

\begin{abstract}
Wiens, M. J., Entz, M. H., Martin, R. C. and Hammermeister, A. M. 2006. Agronomic benefits of alfalfa mulch applied to organically managed spring wheat. Can. J. Plant Sci. 86: 121-131. Field experiments were established at two locations in Manitoba in 2002 and 2003 to determine N contribution, moisture conservation, and weed suppression by alfalfa mulch applied to spring wheat (Triticum aestivum $\mathrm{L}$ ). Mulch treatments included mulch rate (amount harvested from an area $0.5 \times, 1 \times$ and $2 \times$ the wheat plot area), and mulch application timing (at wheat emergence or at three-leaf stage). Positive relationships were observed between mulch rate and wheat $\mathrm{N}$ uptake, grain yield, and grain protein concentration. At Winnipeg, the $2 \times$ mulch rates $(3.9$ to 5.2 $\mathrm{t} \mathrm{ha}^{-1}$ ) produced grain yields equivalent to where 20 and $60 \mathrm{~kg} \mathrm{ha}^{-1}$ of ammonium nitrate-N was applied in 2002 and 2003 , respectively. Where mulch and ammonium nitrate produced equivalent grain yield, grain protein in mulch treatments was often higher than where chemical fertilizer was used. $\mathrm{N}$ uptake was also observed in the following oat (Avena sativa L.) crop. The highest mulch rate $(2 \times)$ produced higher $\mathrm{N}$ uptake and grain yield of second-year oat compared with ammonium nitrate treatments. $\mathrm{N}$ use efficiency of mulch-supplied $\mathrm{N}$ by two crops over 2 yr [calculated as (treatment $\mathrm{N}$ uptake - control $\mathrm{N}$ uptake)/total $\mathrm{N}$ added] was between 11 and $68 \%$. Mulch usually suppressed annual weeds, with greater suppression with late- than early-applied mulch. Increased soil moisture conservation was observed with high mulch rates $\left(\geq 4.3 \mathrm{t} \mathrm{ha}^{-1}\right)$ at three sites. Alfalfa mulch holds promise for low-input cropping systems when used on wheat at the $2 \times$ rates.
\end{abstract}

Key words: Legume N, low-input farming, integrated weed management, wheat protein

Wiens, M. J., Entz, M. H., Martin, R. C. et Hammermeister, A. M. 2006. Bienfaits agronomiques du paillis de luzerne pour la culture biologique du blé de printemps. Can. J. Plant Sci. 86: 121-131. En 2002 et 2003, les auteurs ont effectué des expériences sur le terrain dans deux régions du Manitoba en vue d'établir les effets de l'application d'un paillis de luzerne sur l'apport de N, la conservation de l'eau et la lutte contre les mauvaises herbes dans les champs de blé de printemps (Triticum aestivum L.). Les traitements examinés comprenaient le taux de paillage (quantité récoltée sur une superficie correspondant à $0,5 \times, 1 \times$ et $2 \times$ celle de la parcelle de blé) et le moment de l'application (à la levée ou au stade de trois feuilles). Les auteurs ont noté une corrélation positive entre le taux de paillage et l'absorption de $\mathrm{N}$ par le blé, le rendement grainier et la teneur en protéines du grain. À Winnipeg, le taux de paillage $2 \times$ (de 3,9 à 5,2 t par hectare) a donné un rendement grainier équivalent à celui obtenu avec l'application de 20 ou de $60 \mathrm{~kg}$ par hectare de $\mathrm{N}$ sous forme de nitrate d'ammonium en 2002 et 2003, respectivement. Quand le paillage et l'application de nitrate d'ammonium donnent un rendement grainier équivalent, le grain du blé paillé est souvent plus riche en protéines que celui du blé fertilisé avec des engrais chimiques. On remarque aussi l'absorption de $\mathrm{N}$ par la culture subséquente dans l'assolement (Avena sativa L.). Le taux de paillage le plus élevé $(2 \times)$ entraîne une plus forte absorption de $\mathrm{N}$ et un meilleur rendement grainier de l'avoine cultivée la deuxième année que l'application de nitrate d'ammonium. L'efficacité de l'assimilation du $\mathrm{N}$ venant du paillis par les deux cultures au bout des deux années (calculée comme suit : $\mathrm{N}$ absorbé du paillis - $\mathrm{N}$ absorbé par les témoins)/ $\mathrm{N}$ total ajouté) se situe entre 11 et $68 \%$. En général, le paillis étouffe les mauvaises herbes, mais le fait davantage quand il est appliqué plus tard. Le taux de paillage élevé ( $\geq 4,3$ t par hectare) a accru la conservation de l'eau à trois sites. Le paillis de luzerne s'avère prometteur pour les systèmes de culture à faible apport d'intrants quand on s'en sert au taux $2 \times$ avec le blé.

Mots clés: $\mathrm{N}$ des légumineuses, agriculture rationnelle, lutte intégrée contre les mauvaises herbes, protéines du blé

Increasing alfalfa (Medicago sativa L.) hectares has been proposed as a strategy to increase the sustainability of agriculture in the northern Great Plains (Entz et al. 2002). Especially important to organic farming systems are $\mathrm{N}$ fixation [up to $466 \mathrm{~kg} \mathrm{~N} \mathrm{ha}^{-1}$ per year (Kelner et al. 1997)] and weed suppression (Ominski et al. 1999) provided by perennially grown alfalfa. Recent work in Europe focused on strip farming systems to allow greater inclusion of perennial forages on organic grain farms (Köpke 1998; Schäfer et al. 2002). Schäfer et al. (2002) investigated a system where strips of perennial forage crops were grown between strips

${ }^{3}$ To whom correspondence should be addressed ( $m$ _entz @umanitoba.ca). of annual crops, and a modified forage harvester was used to apply the forage mulch to bare soil, or on top of growing crops. With such a system, the mulch provides nutrients to a crop as it decomposes (Fribourg and Bartholomew 1956), while potentially suppressing weeds (Teasdale et al. 1991) and conserving soil moisture (Yunusa et al. 1994).

Alfalfa mulch contains large amounts of nutrients. An average Manitoba alfalfa hay crop (9.0 $\mathrm{t} \mathrm{ha}^{-1}$, Manitoba Agriculture and Food 2001) contains approximately $278 \mathrm{~kg}$ $\mathrm{N} \mathrm{ha}^{-1}$. In addition, this average alfalfa crop will contain 27 $\mathrm{kg}$ phosphorus, and $223 \mathrm{~kg}$ potassium, per hectare per year, as well as significant amounts of sulfur, calcium, magnesium, iron and other micronutrients (Manitoba Agriculture 
and Food 2001). Replacing the extracted nutrients is a challenge for organic farmers, especially in grain only systems where animal manure availability is limited.

Strips of perennial alfalfa, if grown for use as mulch on adjacent annual crops, would provide farmers with: (1) a new opportunity to extract value from alfalfa top-growth without needing cattle; and (2) a way to grow alfalfa and retain the nutrients on the field that would otherwise be exported if alfalfa hay was sold off the farm. Alfalfa strips could be rotated with annual crops to spread the benefits of this system across an entire field.

Few studies have measured the effects of alfalfa mulch in wheat production; however, several studies suggest that the practice holds promise. Mahler and Hemamda (1993) determined that a fall application of $3 \mathrm{t} \mathrm{ha}^{-1}$ of baled second-cut alfalfa provided $24 \mathrm{~kg} \mathrm{~N} \mathrm{ha}^{-1}$ (26\% of applied $\mathrm{N}$ ) to the following spring wheat crop. Fribourg and Bartholomew (1956) showed that $3.5 \mathrm{t} \mathrm{ha}^{-1}$ of spring-incorporated alfalfa tops provided $44 \mathrm{~kg} \mathrm{~N} \mathrm{ha}^{-1}$ (34\% of applied $\mathrm{N}$ ) to corn, and increased grain yield by $2.09 \mathrm{t} \mathrm{ha}^{-1}$, compared to where no alfalfa was added.

Benefits of alfalfa mulch application will likely persist for more than 1 yr. Uptake of legume-derived $\mathrm{N}$ by crops planted in the second season, or later, after residue application is documented in numerous reports. An Austrian winter pea green manure crop incorporated in early summer provided yield benefits to the following winter wheat crop and to the subsequent barley crop planted 22 mo after the green manure was incorporated. Fribourg and Bartholomew (1950) estimated that oats grown in the second season after application recovered $7.5 \%$ of the total $\mathrm{N}$ applied in alfalfa tops. In South Australia, Ladd et al. (1985) found that $8 \mathrm{yr}$ after incorporating labeled legume residue $31-38 \%$ of the initial legume $\mathrm{N}$ was still present in organic residues in the soil.

If alfalfa mulch is to be considered an effective $\mathrm{N}$ source for wheat it must provide sufficient amounts of $\mathrm{N}$ at critical times during crop development (Sander et al. 1987). Groffman et al. (1987) showed that ammonium nitrate produced a large, short-lived $\mathrm{N}$ pulse, while $\mathrm{N}$ release from legume residue was slower. $\mathrm{N}$ fertilization timing trials in Saskatchewan showed higher wheat yields and lower grain protein concentration with early spring $\mathrm{N}$ application than with late spring $\mathrm{N}$ application (Fowler et al. 1990). Therefore, the benefits of alfalfa mulch-supplied $\mathrm{N}$ may include a long period of $\mathrm{N}$ release resulting in increased wheat grain protein concentration.

Weed suppression with mulch has been reported in a number of previous studies. Teasdale and Mohler (2000) found that mulch applied just before crop emergence suppressed small-seeded weed species; however, larger-seeded species were able to push through the mulch layer. In addition to such physical smothering, mulch can suppress weeds through light interception and modification of soil moisture, temperature and nutrient supply. Teasdale (1993) found light interception to be more important for weed suppression by legume residue than physical impedance. In contrast, increased soil moisture under crop residues has been shown to increase weed emergence (Teasdale and Mohler 1993).

It has long been known that surface soil residues conserve soil moisture (Duley and Russel 1939). This has important implications for regions such as the Canadian prairies where soil moisture is often a limiting factor for crop production (Lafond et al. 1996). Conservation of soil moisture by mulch may reduce yield losses due to inadequate rainfall.

The objective of this project was to investigate the effects of alfalfa mulch applied to wheat (Triticum aestivum L.) by measuring: (1) mulch $\mathrm{N}$ contribution to wheat, in terms of total $\mathrm{N}$ uptake, grain yield, and grain protein concentration; (2) the impact of alfalfa mulch on weed populations; and (3) the effect of alfalfa mulch on soil moisture content.

\section{MATERIALS AND METHODS}

Field studies of mulching effects on a wheat crop were replicated in 2002 and 2003 at both Winnipeg and Carman, MB. The effect of mulch on a second crop of oat that followed wheat was studied only at Winnipeg. Information on soil type and soil nutrient status is summarized in Table 1. Environmental conditions are given in Table 2.

The experimental design was a randomized complete block with four replicates. Canada Western Red spring wheat (cv. AC Barrie) was seeded using a disc drill set at $15-\mathrm{cm}$ row spacing. Plot size was $2 \times 6 \mathrm{~m}$ at Winnipeg, and $2 \times 8 \mathrm{~m}$ at Carman. In year 2, oat (cv. AC Assiniboia) was seeded on all plots at Winnipeg using the same drill.

Sites were tilled prior to seeding. Wheat was seeded at a rate of $135 \mathrm{~kg} \mathrm{ha}^{-1}$. At Winnipeg, wheat was seeded on oat stubble on May 31 and harvested on Sep. 05 in 2002, and was seeded on wheat stubble on May 27 and harvested on Aug. 19 in 2003. At Carman, wheat was seeded on wheat stubble on May 31 and harvested on Sep. 05 in 2002; wheat was seeded on oat stubble on May 27 and harvested on Aug. 26 in 2003.

Following wheat harvest at Winnipeg, straw was removed from plots and plots were tilled using a spring shank cultivator with 20 -cm-wide sweeps and mulching harrows. Plots were cultivated lengthwise to minimize movement of soil between plots. Plots were tilled again the following spring and an oat crop was seeded at a rate of 119 $\mathrm{kg} \mathrm{ha}^{-1}$. In 2003, oat was seeded on May 06 and harvested on Aug. 13. In 2004, oat was seeded on Jun. 10 and harvested on Sep. 24 and 27.

Alfalfa mulch was applied at different rates and at two different wheat development stages: before emergence (Early) and at the three-leaf stage (Late). The base rate of alfalfa mulch used for these experiments was the "natural rate" (Teasdale and Mohler 1993), i.e., the yield $\left(\mathrm{kg} \mathrm{ha}^{-1}\right)$ of alfalfa biomass growing at a location at the time of mulch application. The base rate across site-years ranged from 1.5 $\mathrm{t} \mathrm{ha}^{-1}$ to $3.3 \mathrm{t} \mathrm{ha}^{-1}$ dry weight. The natural rate of mulch was chosen over the fixed rate (i.e., constant amount at all locations and application timings) in order to mimic what may occur in a strip farming system where strips of perennial forages are grown between strips of annual crops. In such a system the amount of mulch available for application on the annual crops is limited to the amount of forage biomass that can be harvested from a field at the time of application. Therefore, the rates of alfalfa mulch applied to wheat were always the amount of alfalfa harvested from an area $0.5 \times, 1 \times$ and $2 \times$ the wheat plot area. Alfalfa dry matter amounts and the application dates are summarized in Table 3. 


\begin{tabular}{|c|c|c|c|c|c|c|c|}
\hline Location & Year & Soil type & Sampling date & Nitrate-N & $\begin{array}{c}\mathrm{P} \\
\left(\mathrm{kg} \mathrm{ha}^{-1}\right.\end{array}$ & K & Sulfate-S \\
\hline Winnipeg & 2002 & Riverdale silty clay & 2002 May 02 & 48.2 & 315.0 & 3130 & 17.9 \\
\hline Carman & 2002 & Hochfeld sandy loam & 2002 May 03 & 53.8 & 78.5 & 1040 & 21.3 \\
\hline Winnipeg & 2003 & Riverdale silty clay & 2002 Oct. 21 & 66.0 & 134.5 & 1270 & 59.4 \\
\hline Carman & 2003 & Reinfeld sandy loam & 2003 Apr. 22 & 118.7 & 54.9 & 600 & 96.4 \\
\hline
\end{tabular}

\begin{tabular}{|c|c|c|c|c|c|c|c|c|}
\hline & \multicolumn{4}{|c|}{ Winnipeg $^{\mathbf{z}}$} & \multicolumn{4}{|c|}{ Carman $^{\mathbf{y}}$} \\
\hline & 2002 & 2003 & 2004 & Long-term ${ }^{\mathrm{x}}$ & & 2002 & 2003 & Long-term $^{\mathrm{w}}$ \\
\hline \multicolumn{9}{|c|}{ Monthly precipitation $(\mathrm{mm})$} \\
\hline Apr. & 18.2 & 15.5 & 19 & 31.9 & Apr. & 12.8 & 32.2 & 38.4 \\
\hline May & 45.1 & 72.6 & 135 & 58.8 & May & 41.4 & 80.2 & 61.1 \\
\hline Jun. & 128.9 & 76.4 & 55 & 89.5 & June & 141.0 & 81.0 & 75.5 \\
\hline Jul. & 97.9 & 42.3 & 61 & 70.6 & July & 49.4 & 56.4 & 73.5 \\
\hline Aug. & 101.6 & 82.2 & 144 & 75.1 & Aug. & 129.2 & 70.8 & 66.8 \\
\hline Sep. & 49.3 & 41 & 111 & 52.3 & Sept. & 21.0 & 36.2 & 59.9 \\
\hline \multicolumn{9}{|c|}{ Average temperature $\left({ }^{\circ} \mathrm{C}\right)$} \\
\hline Apr. & 2.3 & 5.9 & 3.9 & 4.0 & Apr. & 2.3 & 5.5 & 4.4 \\
\hline May & 9 & 13.6 & 8.2 & 12.0 & May & 8.2 & 12.3 & 12.4 \\
\hline Jun. & 18.8 & 17.7 & 15.2 & 17.0 & June & 17.8 & 16.6 & 17.2 \\
\hline Jul. & 22 & 20.6 & 19.4 & 19.5 & July & 20.3 & 19.2 & 19.7 \\
\hline Aug. & 18.6 & 22 & 15.1 & 18.5 & Aug. & 17.8 & 20.7 & 18.1 \\
\hline Sep. & 14.2 & 13.2 & 14.9 & 12.3 & Sept. & 13.7 & 12.4 & 12.2 \\
\hline
\end{tabular}

${ }^{\mathrm{z}}$ Source: Point Weather Station, University of Manitoba, Winnipeg, MB.

ySource: Environment Canada data for University of Manitoba Carman Research Station.

xSource: Environment Canada 30 year average for 1971-2000 at the Winnipeg International Airport.

wSource: Environment Canada 30 year average for 1971-2000 at Graysville, MB.

In addition to mulch treatments, three rates of ammonium nitrate $\left(20,40\right.$, and $60 \mathrm{~kg} \mathrm{~N} \mathrm{ha}^{-1}$ ) and a control (no mulch, no ammonium nitrate) were included. Ammonium nitrate was broadcast-applied on the same date as the early mulch treatment. Alfalfa was harvested from nearby stands with a walk-behind flail mower cutting at approximately $6 \mathrm{~cm}$ above the soil surface. The alfalfa stands ranged between the $2^{\text {nd }}$ and $5^{\text {th }}$ year of production, and were conventionally managed. The mulch was placed into large plastic bags and weighed using a portable beam scale. Mulch application to wheat plots occurred within several hours of mulch harvest. Mulch was applied to the wheat plots by hand with care taken to ensure uniform distribution of mulch across the plot area. At the time of each mulch application, a 1-kg alfalfa mulch sub-sample was weighed, and then dried at $70^{\circ} \mathrm{C}$ to a constant weight to determine the amount of dry matter applied with each treatment. Random sub-samples were also air-dried and analyzed for protein (protein content was divided by 6.25 to determine $\% \mathrm{~N}$ ) and acid detergent fiber content using near-infrared analysis with the Versatile Agri Analyzer Model 5000 (FOSS, Denmark). The carbon to nitrogen ratio was determined by dry combustion with a Leco CNS 2000 (Leco Corp., St. Joseph, MI). Nutrient composition of the mulch is summarized in Table 3.

\section{Measurements}

Weed population density was determined in early July by counting weeds in two, $0.25 \mathrm{~m}^{2}$ quadrats in each plot. Soil moisture content was determined for the $0-$ to $10-\mathrm{cm}$ soil depth every $10 \mathrm{~d}$, beginning after the late mulch application. Samples were taken using a 5-cm-diameter hand auger from between rows at one location per plot. Soil moisture content was determined gravimetrically.

Biomass accumulation in the wheat was determined at anthesis and at the soft dough stage. Above-ground wheat growth was harvested from $0.25 \mathrm{~m}^{2}$ in each plot, dried at $70^{\circ} \mathrm{C}$ for a minimum of $48 \mathrm{~h}$ and then weighed. Biomass samples were ground to pass through a 2-mm screen using a Wiley Mill then sub-sampled for analysis of $\mathrm{N}$ concentration using a dry combustion method with a Leco N Analyzer (model FP-428). Total $\mathrm{N}$ uptake was calculated by multiplying crop biomass $\left(\mathrm{kg} \mathrm{ha}^{-1}\right)$ by $\mathrm{N}$ concentration. $\mathrm{N}$ use efficiency (NUE) was calculated as:

$$
\frac{(\text { treatment } \mathrm{N} \text { uptake }- \text { control } \mathrm{N} \text { uptake })}{\text { total } \mathrm{N} \text { applied }} \times 10(
$$

Grain yield for each treatment was determined by harvesting a pre-determined area from each plot (Table 3) with a small plot combine and weighing the wheat after it had been cleaned. Random sub-samples of grain were ground using a Cyclone Sample Mill; N concentration was determined using the Leco $\mathrm{N}$ Analyzer. Wheat protein concentration was calculated by multiplying $\mathrm{N}$ concentration by 5.7 (Fowler et al. 1990). Oat grain, with hulls still present, was 


\begin{tabular}{|c|c|c|c|c|c|c|c|c|}
\hline Location & Year & Date cut ${ }^{\mathbf{z}}$ & $\mathrm{C}: \mathrm{N}$ & $\% \mathrm{ADF}^{\mathrm{y}}$ & $\% \mathrm{~N}$ in alfalfa & Rate & $\begin{array}{l}\text { Dry matter } \\
\left(\mathrm{t} \mathrm{ha}^{-1}\right)\end{array}$ & $\begin{array}{c}\mathrm{N} \text { applied } \\
\left(\mathrm{kg} \mathrm{ha}^{-1}\right)\end{array}$ \\
\hline \multirow[t]{6}{*}{ Winnipeg } & \multirow[t]{6}{*}{2002} & \multirow[t]{3}{*}{ Jun. 07 (early) } & \multirow[t]{3}{*}{10.54} & \multirow[t]{3}{*}{24.4} & \multirow[t]{3}{*}{4.11} & $0.5 \times$ & 0.97 & 39.9 \\
\hline & & & & & & $1.0 \times$ & 1.97 & 81.0 \\
\hline & & & & & & $2.0 \times$ & 3.94 & 161.9 \\
\hline & & \multirow[t]{3}{*}{ Jun. 21 (late) } & \multirow[t]{3}{*}{13.67} & \multirow[t]{3}{*}{31.0} & \multirow[t]{3}{*}{3.52} & $0.5 \times$ & 1.31 & 46.1 \\
\hline & & & & & & $1.0 \times$ & 2.61 & 91.9 \\
\hline & & & & & & $2.0 \times$ & 5.22 & 183.7 \\
\hline \multirow[t]{6}{*}{ Carman } & \multirow[t]{6}{*}{2002} & \multirow[t]{3}{*}{ Jun. 12 (early) } & \multirow[t]{3}{*}{10.9} & \multirow[t]{3}{*}{24.7} & \multirow[t]{3}{*}{4.19} & $0.5 \times$ & 0.87 & 36.5 \\
\hline & & & & & & $1.0 \times$ & 1.73 & 72.5 \\
\hline & & & & & & $2.0 \times$ & 3.46 & 145.0 \\
\hline & & \multirow[t]{3}{*}{ Jun. 24 (late) } & \multirow[t]{3}{*}{13.62} & \multirow[t]{3}{*}{33.1} & \multirow[t]{3}{*}{3.62} & $0.5 \times$ & 1.44 & 52.1 \\
\hline & & & & & & $1.0 \times$ & 2.88 & 104.3 \\
\hline & & & & & & $2.0 \times$ & 5.76 & 208.5 \\
\hline \multirow[t]{6}{*}{ Winnipeg } & \multirow[t]{6}{*}{2003} & \multirow[t]{3}{*}{ Jun. 02 (early) } & \multirow[t]{3}{*}{11.45} & \multirow[t]{3}{*}{34.1} & \multirow[t]{3}{*}{3.49} & $0.5 \times$ & 0.98 & 34.2 \\
\hline & & & & & & $1.0 \times$ & 1.95 & 68.1 \\
\hline & & & & & & $2.0 \times$ & 3.90 & 136.1 \\
\hline & & \multirow[t]{3}{*}{ Jun. 13 (late) } & \multirow[t]{3}{*}{12.87} & \multirow[t]{3}{*}{38.5} & \multirow[t]{3}{*}{2.74} & $0.5 \times$ & 1.08 & 29.6 \\
\hline & & & & & & $1.0 \times$ & 2.16 & 59.2 \\
\hline & & & & & & $2.0 \times$ & 4.32 & 118.4 \\
\hline \multirow[t]{6}{*}{ Carman } & \multirow[t]{6}{*}{2003} & Jun. 03 (early) & 11.33 & 33.6 & 3.78 & $0.5 \times$ & 0.77 & 29.1 \\
\hline & & & & & & $1.0 \times$ & 1.53 & 57.8 \\
\hline & & & & & & $2.0 \times$ & 3.06 & 115.7 \\
\hline & & Jun. 17 (late) & 14.85 & 42.2 & 2.98 & $0.5 \times$ & 1.66 & 49.5 \\
\hline & & & & & & $1.0 \times$ & 3.32 & 98.9 \\
\hline & & & & & & $2.0 \times$ & 6.64 & 197.9 \\
\hline
\end{tabular}

${ }^{\mathbf{z} E a r l y ~ a p p l i c a t i o n ~ o c c u r r e d ~ j u s t ~ b e f o r e ~ c r o p ~ e m e r g e n c e ~ a n d ~ l a t e ~ a p p l i c a t i o n ~ o c c u r r e d ~ a t ~ t h e ~ t h r e e-l e a f ~ c r o p ~ s t a g e . ~}$

$\mathbf{y}_{\mathrm{ADF}}$, acid detergent fiber.

ground to pass through a 2-mm screen using a Wiley Mill before $\mathrm{N}$ determination using the Leco $\mathrm{N}$ Analyzer. A factor of 6.25 was used to convert oat $\mathrm{N}$ concentration to protein (Biston and Clamot 1982). Grain N yield was calculated by multiplying grain yield $\left(\mathrm{kg} \mathrm{ha}^{-1}\right)$ by $\mathrm{N}$ concentration in the grain.

Second-year oat crop biomass was determined from plant samples taken at the soft-dough stage. Fowler et al. (1990) suggested the soft-dough stage to be the point of maximum $\mathrm{N}$ accumulation in wheat. Biomass samples were ground, sub-sampled and analyzed for $\mathrm{N}$ content as described for the wheat biomass samples, and total $\mathrm{N}$ uptake was calculated by multiplying biomass yield by $\mathrm{N}$ concentration. Oat grain yield was determined using the same methods as for wheat.

\section{Statistical Analysis}

The Proc GLM procedure (SAS Institute, Cary, NC) was used to analyze variance on all parameters. Effects were considered significant at a $P$ value of $<0.05$ unless otherwise indicated. Where significant treatment effects were detected, treatment means were compared using Fisher's protected Least Significant Difference (LSD). Bartlett's test for homogeneity of variance was used on weed numbers data to assure uniformity of variance between treatments.

The nature of the response (linear, quadratic) to the quantitative levels of a factor (mulch rate, ammonium nitrate rate) were evaluated using sets of orthogonal polynomial contrasts (Gill 1978). Other contrasts representing questions of interest were also included, for example, early treatments versus late treatments.

\section{RESULTS AND DISCUSSION}

In general, alfalfa mulch had positive effects on wheat crop performance and mulch benefits increased with mulch rate. In several instances differences were detected between early and late mulch applications; however, mulch application rate was a more important factor than mulch application timing.

\section{Stand Establishment and Surface Soil Water Content}

Carman in 2003 was the only site-year where mulch application reduced wheat plant stand compared to the control ( 297 plants $\mathrm{m}^{-2}$ in the control vs. 213 plants $\mathrm{m}^{-2}$ for the late $2 \times$ application). This late application of the $2 \times$ rate was the highest rate $\left[6.6 \mathrm{t} \mathrm{ha}^{-1}\right.$ (dry basis)] of mulch used in this study. Plant stand reduction was most likely caused by physical smothering. Yunusa et al. (1994) found no difference in the plant population density between control plots and wheat plots mulched with wheat straw at a rate of $8 \mathrm{t} \mathrm{ha}^{-1}$ when mulch was applied $36 \mathrm{~d}$ after seeding (at floral initiation). Nevertheless, the loss of plants at Carman 2003 suggests that a rate of $6.6 \mathrm{t} \mathrm{ha}^{-1}$ of alfalfa mulch applied at the three-leaf stage may be excessive for optimum wheat plant establishment.

Soil water content results indicated that the $2 \times$ Late mulch rates ( 4.3 to $6.6 \mathrm{t} \mathrm{ha}^{-1}$ ) conserved moisture (between 2.2 and $3.8 \%$ higher than the control) at three of the four site-years (data not shown). Moisture conservation benefits of mulch were restricted to the period prior to wheat canopy closure. However, average to above average precipitation in both 
Table 4. The effect of alfalfa mulch rate and application timing on total weed population density at Winnipeg and Carman in 2002 and 2003

\begin{tabular}{|c|c|c|c|c|}
\hline \multirow[b]{3}{*}{ Treatment $^{\mathrm{Z}}$} & \multicolumn{2}{|c|}{2002} & \multicolumn{2}{|c|}{2003} \\
\hline & Winnipeg & Carman & Winnipeg & Carman \\
\hline & \multicolumn{4}{|c|}{$-\left(\right.$ weeds $\left.\mathrm{m}^{-2}\right)$} \\
\hline Control & $35.5 a b$ & $1639 a b c$ & $139 b c$ & $27 c$ \\
\hline $20 \mathrm{~kg} \mathrm{~N}$ & $47.5 a$ & $1911 a b c$ & $\mathrm{ND}^{\mathbf{y}}$ & ND \\
\hline $40 \mathrm{~kg} \mathrm{~N}$ & $38.5 A b$ & $1583 a b c$ & ND & ND \\
\hline $60 \mathrm{~kg} \mathrm{~N}$ & $61.5 A$ & $1778 a b$ & $113 b c$ & $37 c$ \\
\hline $0.5 \times$ Early & $50.0 \mathrm{~A}$ & $1565 a b c$ & $243 a$ & $306 b$ \\
\hline $1 \times$ Early & $61.5 A$ & $940 d$ & $197 a b$ & $447 a$ \\
\hline $2 \times$ Early & $42.0 A b$ & $1184 c d$ & $114 b c$ & $449 a$ \\
\hline $0.5 \times$ Late & $36.0 \mathrm{Ab}$ & $1458 a b c d$ & $156 \mathrm{a} b c$ & $30 c$ \\
\hline $1 \times$ Late & $15.0 B c$ & $1302 b c d$ & $131 b c$ & $31 c$ \\
\hline $2 \times$ Late & $6.5 C$ & $915 d$ & $90 c$ & $18 c$ \\
\hline $\operatorname{LSD}(P=0.05)$ & 28.9 & 580 & 103 & 127 \\
\hline$P>F$ & 0.009 & 0.0172 & 0.0925 & $<0.0001$ \\
\hline Mean & 39.4 & 1427 & 148 & 168.0 \\
\hline
\end{tabular}

Contrasts 0.0005

Early - linear (by rate) 0.4321

Late - linear (by rate) 0.0605

0.9766

0.3321

0.0584

0.0493

0.0151

$<0.0001$

$\mathrm{CV}(\%)$

50.57

28.01

47.31

51.02

${ }^{\mathrm{z}} 0.5 \times, 1 \times$ and $2 \times$ refer to the amount of alfalfa harvested from an area 0.5 , 1 and 2 times the wheat plot area. Refer to Table 3 for mulch dry matter rates. The 20, 40, $60 \mathrm{~kg} \mathrm{~N}$ treatments consisted of 20,40 and $60 \mathrm{~kg} \mathrm{~N} \mathrm{ha}^{-1}$ applied as ammonium nitrate. Early application timing was before wheat emergence. Late application timing was at the three-leaf stage.

${ }^{\mathrm{y} N D}$, not determined.

$a-d$ Means followed by the same letter within a column are not significantly different $(P>0.05)$ according to Fischer's protected LSD.

years caused frequent wet conditions that reduced moisture differences between treatments.

\section{Weeds}

In 2002, fewer weeds were observed in the $2 \times$ Late mulch treatment than in the control at both locations (Table 4). Teasdale et al. (1991) and Teasdale and Mohler (2000) observed that rye (Secale cereale L.) and hairy vetch (Vicia villosa Roth) mulches at rates greater than $3 \mathrm{t} \mathrm{ha}^{-1}$ reduced weed density. Reductions in weeds with a $3 \mathrm{t} \mathrm{ha}^{-1}$ mulch application (see Table 3 ) were not consistently observed (Table 4). This was in part due to low weed densities in the control treatments. Despite weed suppression with the $2 \times$ Late treatment at Carman in 2002, weeds were still numerous and of agronomic importance.

For Late treatments in 2002, and the Early treatment at Winnipeg in 2003 there was a decrease $(P=0.1)$ in weed density as mulch rate increased (see contrasts in Table 4). Better weed suppression with high mulch rates than low mulch rates may have been due to a number of factors including greater effects on light interception, physical impedance, and alterations to the microclimate as mulch rate increased. However, there may also have been some stimulation of weed germination at low mulch rates that contributed to the differences in weed population density between mulch treatments.
Low mulch rates may stimulate weed seedling recruitment. At Winnipeg in 2003, for example, weed density in the $0.5 \times$ Early treatment was higher than in the control $(P=$ 0.1 , Table 4). This may be a result of increased soil moisture levels due to mulch application, and resulting stimulation of germination (Teasdale and Mohler 1993). Weed suppression at higher mulch rates may have countered the benefits of improved soil moisture for weed germination.

Purslane (Portulaca oleracea L.) and foxtail spp. [Setaria viridis (L.) Beauv. and Setaria glauca (L.) Beauv.] contributed most to the higher weed density in the $0.5 \times$ Early treatment than in the $60 \mathrm{~kg} \mathrm{~N}$ treatment at Winnipeg 2003. Work by Boyd and Van Acker (2003) showed greater green foxtail [Setaria viridis (L.) Beauv.] emergence when seeds were slightly buried in the soil than when placed on the soil surface. Mulch application may have provided similar conditions for foxtail seeds on the soil surface as would exist for slightly buried seeds, and thus contributed to the higher density in the early $0.5 \times$ plots.

At Winnipeg in both 2002 and 2003, weed density was higher in the Early mulch treatments than the Late mulch treatments (see contrasts in Table 4). More mulch was applied with the Late treatments than the Early treatments and the greater smothering effect of higher mulch amounts may account for the lower weed density in these treatments. In addition to the difference in mulch amount, application timing may have played a role. Early mulch application allowed for earlier mulch degradation and may have allowed greater weed growth through mulch than Late mulch treatments. Early mulch application may also have allowed timely $\mathrm{N}$ availability to germinating weeds (Blum et al. 1997). Teasdale and Mohler (2000) found that more rapid mulch degradation may have accounted for higher redroot pigweed (Amaranthus retroflexus L.) numbers in one year compared with another.

At Carman in 2002 there was no difference in total weed numbers between the early and late mulch applications. However, when separated by species, dandelion (Taraxacum officinale Weber in Wiggers) was more prevalent with the Early treatments than the Late treatment; possibly indicating that seeds were added to the plots with the Early mulch application.

Weed population density results at Carman in 2003 were dramatically different from all other site-years. Here Early mulch application caused a dramatic increase in weed populations compared with all other treatments (Table 4). The extra weeds emerging in these treatments were almost exclusively dandelion. Increased dandelion emergence in the Early mulch treatments occurred because high numbers of dandelion seeds were harvested with the alfalfa and applied to the wheat plots at that time. The mulch harvested 2 wk later for the Late treatment contained almost no dandelion seeds. Average dandelion population density in the $2 \times$ Early treatment was 428 plants $\mathrm{m}^{-2}$ compared with 1 plant $\mathrm{m}^{-2}$ in the $2 \times$ Late treatment (data not shown).

In a study of weed seed germination, Chepil (1946) observed that dandelion seed had a maximum dormancy of $4 \mathrm{yr}$ and had no marked periodicity of germination throughout the growing season. These germination characteristics 
Table 5. Effect of alfalfa mulch application rate and application timing on wheat $\mathrm{N}$ uptake measured at the soft-dough stage, and on grain yield and grain protein concentration (GPC) at Winnipeg and Carman in 2002

\begin{tabular}{|c|c|c|c|c|c|c|}
\hline \multirow[b]{2}{*}{ Treatment $^{\mathrm{Z}}$} & \multicolumn{2}{|c|}{ Winnipeg } & \multirow[b]{2}{*}{$\begin{array}{c}\text { GPC } \\
\left(\mathrm{g} \mathrm{kg}^{-1}\right)\end{array}$} & \multicolumn{3}{|c|}{ Carman } \\
\hline & $\mathrm{N}$ uptake & Grain yield & & $\mathrm{N}$ uptake & Grain yield & $\begin{array}{c}\mathrm{GPC} \\
\left(\mathrm{g} \mathrm{kg}^{-1}\right)\end{array}$ \\
\hline Control & $34.5 \mathrm{~g}$ & $775 e$ & $147 b c$ & $50.1 c$ & $403 b$ & 154 \\
\hline $20 \mathrm{~kg} \mathrm{~N}$ & $50.9 \mathrm{cde}$ & $1072 c d$ & $141 c d$ & $72.4 a b$ & $729 a$ & 150 \\
\hline $40 \mathrm{~kg} \mathrm{~N}$ & $62.7 b$ & $1534 b$ & $141 c d$ & $71.1 a b$ & $825 a$ & 156 \\
\hline $60 \mathrm{~kg} \mathrm{~N}$ & $92.6 a$ & $1954 a$ & $136 d$ & $81.8 a$ & $842 a$ & 157 \\
\hline $0.5 \times$ Early & $44.8 \mathrm{def}$ & 831de & $153 a b$ & $64.1 b c$ & $655 a$ & 154 \\
\hline 1.0×Early & $44.7 \mathrm{def}$ & $929 c d e$ & $149 a b$ & $71.3 a b$ & $804 a$ & 160 \\
\hline 2.0×Early & $56.7 b c$ & $1148 c$ & $154 a b$ & $70.7 a b$ & $800 a$ & 156 \\
\hline $0.5 \times$ Late & $38.6 \mathrm{fg}$ & $852 d e$ & $148 a b c$ & $71.9 a b$ & $752 a$ & 155 \\
\hline $1.0 \times$ Late & $42.5 \mathrm{e} f g$ & $852 d e$ & $153 a b$ & $66.7 a b$ & $850 a$ & 156 \\
\hline $2.0 \times$ Late & $53.2 b c d$ & $1163 c$ & $155 a$ & $77.6 a b$ & $795 a$ & 165 \\
\hline LSD (0.05) & 10.02 & 245 & 7 & 15.78 & 208 & $\mathrm{NS}^{\mathrm{y}}$ \\
\hline
\end{tabular}

\begin{tabular}{llcccrr}
$P>F$ & $<0.0001$ & $<0.0001$ & $<0.0001$ & 0.0351 & 0.0052 & 0.0621 \\
\hline Mean & 52.11 & 1111 & 148 & 69.78 & 744 & 156 \\
\hline CV $(\%)$ & 13.2 & 15.2 & 3.3 & 15.58 & 18.9 & 3 \\
\hline
\end{tabular}

\section{Contrasts}

Early vs. Late $\quad 0.1732 \quad 0.8485 \quad 0.9405$

Early-linear (by rate) $0.0132 \quad 0.0113 \quad 0.6943$

$\begin{array}{llll}\text { Late-linear (by rate) } & 0.0047 & 0.0084 & 0.0767\end{array}$

0.4601

0.4679

0.3438

0.4948
0.218
0.9319

0.5468

${ }^{\mathrm{z}_{0}} 0.5 \times, 1 \times$ and $2 \times$ refer to the amount of alfalfa harvested from an area $0.5,1$ and 2 times the wheat plot area. Refer to Table 3 for amounts of alfalfa mulch applied. The 20,40, $60 \mathrm{~kg} \mathrm{~N}$ treatments consisted of 20,40 and $60 \mathrm{~kg} \mathrm{~N}^{-1}$ applied as ammonium nitrate. Early application timing was before wheat emergence. Late application timing was at the three-leaf stage.

$\mathbf{y}_{\mathrm{NS}}$, non-significant.

$a-e$ Means followed by the same letter within a column are not significantly different $(P>0.05)$ according to Fisher's protected LSD.

Table 6. Effect of alfalfa mulch application rate and application timing on wheat $\mathrm{N}$ uptake measured at the soft-dough stage, and on grain yield and grain protein concentration (GPC) at Winnipeg and Carman in 2003

\begin{tabular}{|c|c|c|c|c|c|c|}
\hline \multirow[b]{2}{*}{ Treatment $^{\mathrm{Z}}$} & \multicolumn{3}{|c|}{ Winnipeg } & \multicolumn{3}{|c|}{ Carman } \\
\hline & $\mathrm{N}$ uptake & Grain Yield & $\begin{array}{c}\mathrm{GPC} \\
\left(\mathrm{g} \mathrm{kg}^{-1}\right)\end{array}$ & $\mathrm{N}$ uptake & Grain yield & $\begin{array}{c}\mathrm{GPC} \\
\left(\mathrm{g} \mathrm{kg}^{-1}\right)\end{array}$ \\
\hline Control & $38.3 d$ & $1111 c$ & $150 b c d$ & 164 & 2308 & $159 c$ \\
\hline $20 \mathrm{~kg} \mathrm{~N}$ & $54.1 b c d$ & $1468 b c$ & $148 b c d$ & 181 & 2089 & $165 b$ \\
\hline $40 \mathrm{~kg} \mathrm{~N}$ & $79.1 b c$ & $2225 a$ & $143 d$ & 157 & 2334 & $167 b$ \\
\hline $60 \mathrm{~kg} \mathrm{~N}$ & $108.9 a$ & $2412 a$ & $147 c d$ & 180 & 2091 & $175 a$ \\
\hline $0.5 \times$ Early & $51.0 \mathrm{~cd}$ & $1377 b c$ & $155 a b$ & 168 & 2146 & $167 b$ \\
\hline $1.0 \times$ Early & $54.7 b c d$ & $1575 b$ & $149 b c d$ & 198 & 2046 & $166 b$ \\
\hline 2.0×Early & $71.5 b c$ & $2191 a$ & $154 a b c$ & 198 & 2234 & $175 a$ \\
\hline $0.5 \times$ Late & $58.5 b c d$ & $1320 b c$ & $149 b c d$ & 184 & 2148 & $166 b$ \\
\hline $1.0 \times$ Late & $60.1 \mathrm{bcd}$ & $1687 b$ & $158 a$ & 195 & 2318 & $167 b$ \\
\hline $2.0 \times$ Late & $81.8 a b$ & $2137 a$ & $153 a b c$ & 203 & 1953 & $180 a$ \\
\hline LSD (0.05) & 29.14 & 434 & 7 & $\mathrm{NS}^{\mathbf{y}}$ & NS & 6 \\
\hline$P>F$ & 0.001 & $<0.0001$ & 0.01 & 0.057 & 0.0731 & $<0.0001$ \\
\hline Mean & 65.80 & 1750 & 151 & 182 & 2165 & 169 \\
\hline $\mathrm{CV}(\%)$ & 28.5 & 17.1 & 3.3 & 12 & 8.7 & 2.5 \\
\hline \multicolumn{7}{|l|}{ Contrasts } \\
\hline Early vs. Late & 0.4799 & 0.998 & 0.675 & 0.4849 & 0.0969 & 0.2985 \\
\hline Early-linear (by rate) & 0.1166 & 0.0004 & 0.9779 & 0.107 & 0.4852 & 0.0044 \\
\hline Late-linear (by rate) & 0.0826 & 0.0007 & 0.5624 & 0.3563 & 0.0244 & $<0.0001$ \\
\hline
\end{tabular}

${ }^{\mathrm{z}} 0.5 \times, 1 \times$ and $2 \times$ refer to the amount of alfalfa harvested from an area $0.5,1$ and 2 times the wheat plot area. Refer to Table 3 for amounts of alfalfa mulch applied. The $20,40,60 \mathrm{~kg} \mathrm{~N}$ treatments consisted of 20,40 and $60 \mathrm{~kg} \mathrm{~N} \mathrm{ha}^{-1}$ applied as ammonium nitrate. Early application timing was before wheat emergence. Late application timing was at the three-leaf stage.

yS, non-significant.

$a-d$ Means followed by the same letter within a column are not significantly different $(P>0.05)$ according to Fisher's protected LSD.

of dandelion indicate that, if present in the mulch, germination may occur regardless of when application occurs and may continue to occur throughout the growing season and for several years thereafter. 


\section{Wheat $\mathrm{N}$ uptake}

Alfalfa mulch application at the $2 \times$ rates increased $\mathrm{N}$ uptake compared with control plots in 3 out of 4 site years, regardless of application timing (Tables 5 and 6). Increased plant $\mathrm{N}$ uptake with mulch treatments was detected at the anthesis sampling (data not shown), but was more pronounced at the soft-dough stage. Carman in 2003 was the only site where no significant mulch or ammonium nitrate effect on $\mathrm{N}$ uptake was observed (Table 6). This lack of response was probably due to a high residual soil $\mathrm{N}$ level at the beginning of the growing season (Table 1).

At Winnipeg in 2002 and 2003, both timings of the $2 \times$ mulch treatments increased total $\mathrm{N}$ uptake over the control (Tables 5 and 6). These treatments had $\mathrm{N}$ uptake comparable with the $40 \mathrm{~kg} \mathrm{~N}^{-1}$ ammonium nitrate treatment (Tables 5 and 6). The Early $0.5 \times$ and $1 \times$ treatments at Winnipeg in 2002 also showed higher $\mathrm{N}$ uptake than the control, but the Late $0.5 \times$ and $1 \times$ treatments did not, and neither did the Early or Late $0.5 \times$ and $1 \times$ treatments in 2003 . There was a positive relationship between mulch rate and plant $\mathrm{N}$ uptake in 2002 but not in 2003 (contrasts in Table 5 and 6). At Carman in 2002, all mulch treatments with the exception of the $0.5 \times$ Early treatment had significantly higher $\mathrm{N}$ uptake than the control (Table 5). $\mathrm{N}$ uptake for most treatments was equivalent to the $60 \mathrm{~kg} \mathrm{~N}$ ha $^{-1}$ ammonium nitrate treatment, demonstrating a very positive mulch effect at this site. Increasing alfalfa mulch rate from $0.5 \times$ to $2 \times$ did not increase wheat N uptake at this site (Table 5). In 2002, the higher total $\mathrm{N}$ uptake at Carman $\left(\right.$ avg. $\left.=69.8 \mathrm{~kg} \mathrm{ha}^{-1}\right)$ than Winnipeg $\left(\right.$ avg. $\left.=52.1 \mathrm{~kg} \mathrm{ha}^{-1}\right)$ was likely a response to higher initial soil nitrate-N levels at Carman (Table 1), and the effect of historic alfalfa cropping on this field.

Timing of mulch application had no effect on $\mathrm{N}$ uptake (contrasts in Tables 5 and 6). The positive wheat response to both timings of mulch application indicates that $\mathrm{N}$ release from the Late-applied alfalfa was relatively quick. Alternatively, the higher application rates of mulch at the Late timing compensated for the delayed $\mathrm{N}$ release. Rapid N availability from legume residues was observed by Cueto Wong et al. (2001); the highest inorganic soil N levels were measured $14 \mathrm{~d}$ after spring incorporation of alfalfa or hairy vetch. However, in the present study, higher $\mathrm{N}$ uptake in mulch plots than in the control, did not always correspond with increases in yield, as is discussed below.

\section{Wheat Grain Yield}

Grain yields in the present study (Tables 5 and 6) were within the range $\left(672-2690 \mathrm{~kg} \mathrm{ha}^{-1}\right)$ of wheat yields on 14 organic farms surveyed in Manitoba, Saskatchewan, and North Dakota (Entz et al. 2001). Grain yield response to mulch application at both locations was higher in 2003 than in 2002. High levels of precipitation in $2002(\sim 370 \mathrm{~mm}$ from May 01 to Aug. 30) stressed wheat plants and provided ideal conditions for leaf disease development.

Wheat grain yield followed patterns similar to plant $\mathrm{N}$ uptake. At Winnipeg, yield increased with mulch rate, regardless of application timing or year (contrasts in Tables 5 and 6). At Winnipeg, wheat yield of the $2 \times$ Early and
$2 \times$ Late treatments was the same as for the $20 \mathrm{~kg} \mathrm{~N} \mathrm{ha}^{-1}$ ammonium nitrate treatment in 2002, and the 40 and $60 \mathrm{~kg}$ $\mathrm{ha}^{-1}$ ammonium nitrate- $\mathrm{N}$ treatments in 2003; there were no differences among these treatments (Table 6). The $1 \times$ treatments at Winnipeg resulted in higher grain yield than the control only in 2003; other $0.5 \times$ and $1 \times$ treatments were equivalent to the control (Tables 5 and 6.)

These yield results agree with the findings of Mahler and Hemamda (1993) who showed that 2 and $3 \mathrm{t} \mathrm{ha}^{-1}$ of fallapplied alfalfa hay, containing 62 and $93 \mathrm{~kg} \mathrm{~N} \mathrm{ha}^{-1}$, respectively, increased wheat yields compared with the control. In contrast, Schäfer et al. (2002) found that spring wheat yields were depressed by $2.3 \mathrm{t} \mathrm{ha}^{-1}$ of red clover (Trifolium pretense)/timothy (Phleum pretense)/meadow fescue (Festuca pratensis) mulch. They attributed the yield depression to low amounts of $\mathrm{N}$ added with the mulch $\left(45 \mathrm{~kg} \mathrm{~N} \mathrm{ha}^{-1}\right)$ and low $\mathrm{N}$ mineralization due to cold, dry weather. Higher amounts of $\mathrm{N}$ were added with mulch in the present study (up to $209 \mathrm{~kg} \mathrm{~N} \mathrm{ha}^{-1}$ ) (Table 3).

Grain yield at Carman in 2002 was very low as a result of excessive moisture in June and the high weed competition. However, yield was higher in all mulch treatments than in the control (Table 5); no application timing or rate effect was measured. In 2003, no treatment effect was measured despite high yields (Table 6). The lack of a yield response was probably due to high indigenous soil $\mathrm{N}$ (Table 1) and also reduced wheat plant density in the $2 \times$ Late treatment (as described above). The low crop density explains the negative rate effect of the mulch application in 2003 (see the Late linear contrast in Table 6).

\section{Wheat Grain Protein Concentration}

Achieving high grain protein concentration is a challenge in organic farming systems, which are sometimes N-limited (Entz et al. 2001). While protein levels in the range of 13.0 to $13.5 \mathrm{~g}$ $\mathrm{kg}^{-1}$ are typically desired, the Canadian Wheat Board will pay premiums for high protein contents up to $15 \mathrm{~g} \mathrm{~kg}^{-1}$. Exceptionally high protein content $\left(>15 \mathrm{~g} \mathrm{~kg}^{-1}\right)$ is less desirable due to practical storage and blending constraints. Protein content in this study ranged from 13.6 to $18.0 \mathrm{~g} \mathrm{~kg}^{-1}$. Treatment effects on grain protein were observed in all site years except Carman in 2002. An increase in grain protein concentration with mulch application rate was observed with the Late mulch treatments at Carman 2002, and with both timings in 2003; no such effect was observed at Winnipeg (see contrasts in Tables 5 and 6). Grain protein was higher than the control in all treatments at Carman in 2003. In this site year, the $2 \times$ rates of mulch and $60 \mathrm{~kg} \mathrm{~N} \mathrm{ha}^{-1}$ rate of ammonium nitrate resulted in higher protein than all of the low and medium rate treatments, among which there were no differences. In addition to higher available $\mathrm{N}$ from the mulch, lower crop density (described above) may have contributed to the high protein content in the $2 \times$ Late treatment and the observed rate effect in the Late contrast (Table 6). Considering there was no treatment effect on grain yield or $\mathrm{N}$ uptake at Carman in 2003, but there was a positive rate effect on grain protein, $\mathrm{N}$ supplied by the mulch was primarily used to increase grain protein concentration. The benefit of delayed mineralization of $\mathrm{N}$ in the mulch was not 
Table 7. Effect of alfalfa mulch application rate and application timing on second-year nitrogen uptake, and grain yield of oats grown at Winnipeg in 2003 and 2004 on plots that grew mulch-treated wheat in 2002 and 2003

\begin{tabular}{|c|c|c|c|c|c|}
\hline \multirow[b]{2}{*}{ Treatment $^{\mathrm{Z}}$} & \multicolumn{3}{|c|}{2003} & \multicolumn{2}{|c|}{2004} \\
\hline & $\mathrm{N}$ uptake & Yield & $\begin{array}{l}\text { Grain N yield } \\
-\left(\mathrm{kg} \mathrm{ha}^{-1}\right) \\
\end{array}$ & $\mathrm{N}$ uptake & Yield \\
\hline Control & 52.0 & $2101 c$ & $32.3 D$ & $34.2 d$ & $1747 c$ \\
\hline $20 \mathrm{kgN}$ & 56.8 & $2461 b c$ & $38.6 C d$ & $34.3 d$ & $1782 c$ \\
\hline $40 \mathrm{kgN}$ & 59.7 & $2747 B$ & $44.4 c$ & $39.3 d$ & $1827 c$ \\
\hline $60 \mathrm{kgN}$ & 57.3 & $2567 b c$ & $39.8 c d$ & $37.1 d$ & $1812 c$ \\
\hline 0.5(Early & 64.3 & $2967 a b$ & $46.5 c$ & $39.4 d$ & $2069 b c$ \\
\hline 1×Early & 50.7 & $2897 B$ & $44.0 c$ & $42.2 b c d$ & $2042 c$ \\
\hline 2×Early & 60.4 & $3531 A$ & $55.9 a b$ & $55.9 a$ & $2765 a$ \\
\hline $0.5 \times$ Late & 56.2 & $2570 b c$ & $39.1 c d$ & $40.7 c d$ & $1834 c$ \\
\hline $1 \times$ Late & 60.4 & $3022 a b$ & $47.4 b c$ & $51.7 a b$ & $2469 a b$ \\
\hline $2 \times$ Late & 68.5 & $3528 A$ & $57.0 a b$ & $50.2 a b c$ & $2809 A$ \\
\hline $\operatorname{LSD}(0.05)$ & $\mathrm{NS}^{\mathbf{y}}$ & 570 & 9.1 & 9.7 & 401 \\
\hline$P>F$ & 0.9442 & 0.001 & 0.0004 & 0.005 & 0.0001 \\
\hline Mean & 58.6 & 2814 & 44.13 & 42.5 & 2112 \\
\hline $\mathrm{CV}(\%)$ & 30.3 & 13.2 & 13.5 & 15.8 & 13.1 \\
\hline $\begin{array}{l}\text { Contrast } \\
\text { Early vs. Late }\end{array}$ & 0.6593 & 0.5813 & 0.7026 & 0.534 & 0.4401 \\
\hline
\end{tabular}

$\mathrm{z}_{0.5 \times, 1 \times}$ and $2 \times$ refer to the amount of alfalfa harvested from an area $0.5,1$ and 2 times the wheat plot area. Refer to Table 3 for amounts of alfalfa mulch applied. The 20,40, $60 \mathrm{~kg} \mathrm{~N}$ treatments consisted of 20,40 and $60 \mathrm{~kg} \mathrm{~N} \mathrm{ha}^{-1}$ applied as ammonium nitrate. Early application timing was before wheat emergence. Late application timing was at the three-leaf stage.

$\mathrm{y}_{\mathrm{NS}}$, non-significant.

$a-d$ Means followed by the same letter within a column are not significantly different $(P>0.05)$ according to Fisher's protected LSD.

Table 8. Effect of alfalfa mulch application rate and application timing on total $\mathrm{N}$ uptake, and $\mathrm{N}$ use efficiency (NUE) over 2 years (2002 and 2003 ) at Winnipeg

\begin{tabular}{|c|c|c|c|c|c|}
\hline \multirow[b]{2}{*}{ Treatment $^{\mathrm{Z}}$} & \multicolumn{2}{|c|}{2002 Wheat } & \multirow{2}{*}{$\begin{array}{l}2003 \text { oat } \\
\text { NUE } \\
(\%)\end{array}$} & \multirow{2}{*}{$\begin{array}{l}\text { Combined } 2002+2003 \\
2-y r ~ N \text { uptake } \\
\left(\mathrm{kg} \mathrm{ha}^{-1}\right)\end{array}$} & \multirow[b]{2}{*}{$\begin{array}{c}2-y r \text { NUE } \\
(\%)\end{array}$} \\
\hline & $\begin{array}{c}\mathrm{N} \text { applied } \\
\left(\mathrm{kg} \mathrm{ha}^{-1}\right)\end{array}$ & $\begin{array}{l}\mathrm{NUE}^{\mathrm{y}} \\
(\%)\end{array}$ & & & \\
\hline Control & - & - & - & $86.4 d$ & - \\
\hline $20 \mathrm{~kg} \mathrm{~N}$ & 20 & $82.2 a$ & 24.1 & $107.7 b c d$ & $106.4 a$ \\
\hline $40 \mathrm{~kg} \mathrm{~N}$ & 40 & $70.6 a$ & 19.4 & $122.4 b$ & $90.1 a$ \\
\hline $60 \mathrm{~kg} \mathrm{~N}$ & 60 & $97.0 a$ & 8.9 & $150.0 a$ & $105.9 a$ \\
\hline $0.5 \times$ Early & 40 & $25.9 b$ & 30.8 & $109.1 b c d$ & $56.7 a b$ \\
\hline 1×Early & 81 & $12.6 b$ & -1.6 & $95.4 b c d$ & $11.1 b$ \\
\hline 2×Early & 162 & $13.7 b$ & 5.2 & $117.0 b c$ & $18.9 b$ \\
\hline $0.5 \times$ Late & 46 & $9.0 b$ & 9.1 & $94.8 c d$ & $18.2 b$ \\
\hline $1 \times$ Late & 92 & $8.8 b$ & 9.2 & $102.9 b c d$ & $18.0 b$ \\
\hline $2 \times$ Late & 184 & $10.2 b$ & 9.0 & $121.7 b c$ & $19.2 b$ \\
\hline $\operatorname{LSD}(0.05)$ & 26.4 & $\mathrm{NS}^{\mathbf{x}}$ & 27.4 & 57.9 & \\
\hline$P>F$ & $<0.0001$ & 0.9651 & 0.0038 & 0.0027 & \\
\hline Mean & 36.7 & 12.7 & 110.7 & 49.4 & \\
\hline $\mathrm{CV}(\%)$ & 49.3 & 299.7 & 17.1 & 80.4 & \\
\hline
\end{tabular}

$\begin{array}{lrrrr}\text { Early vs. Late } & 0.2849 & 0.8788 & 0.9269 & 0.5245\end{array}$

${ }^{\mathrm{z}} 0.5 \times, 1 \times$ and $2 \times$ refer to the amount of alfalfa harvested from an area $0.5,1$ and 2 times the wheat plot area. The $20,40,60 \mathrm{~kg} \mathrm{~N}$ treatments consisted of 20 , 40 and $60 \mathrm{~kg} \mathrm{~N} \mathrm{ha}^{-1}$ applied as ammonium nitrate. Early application timing was before wheat emergence. Late application timing was at the three-leaf stage.

$\mathbf{y}_{\text {Nitrogen use efficiency }(\mathrm{NUE})}=(($ treatment $\mathrm{N}$ uptake - control $\mathrm{N}$ uptake $) / \mathrm{N}$ applied $) \times 100$.

$\mathbf{x}_{\mathrm{NS}}$, non-significant.

$a-d$ Means followed by the same letter within a column are not significantly different $(P>0.05)$ according to Fisher's protected LSD.

observed, as the ammonium nitrate treatments provided the same trends. For other site years, clear timing and rate effects of mulch application were not observed.

Despite generally lower $\mathrm{N}$ uptake in mulch plots at Winnipeg in 2002, grain protein concentration of mulch plots was generally higher than in the ammonium nitrate treatments (Table 5). When comparing the mulch treatments (except $0.5 \times$ Late) to the $20 \mathrm{~kg} \mathrm{ha}^{-1}$ ammonium nitrate treatment in Winnipeg in 2002, the $\mathrm{N}$ uptake and yield are not different. The grain protein concentration, however, is higher in all mulch treatments. This supports the assertion that the slower release of $\mathrm{N}$ from the mulch is more likely to con- 
Table 9. Effect of alfalfa mulch application rate and application timing on total $\mathrm{N}$ uptake and $\mathrm{N}$ use efficiency (NUE) over 2 yr (2003 and 2004$)$ at Winnipeg

\begin{tabular}{|c|c|c|c|c|c|}
\hline \multirow[b]{2}{*}{ Treatment $^{\mathbf{z}}$} & \multicolumn{2}{|c|}{2003 wheat } & \multirow{2}{*}{$\begin{array}{c}2004 \text { oats } \\
\text { NUE } \\
(\%)\end{array}$} & \multicolumn{2}{|c|}{ Combined $2003+2004$} \\
\hline & $\begin{array}{c}\mathrm{N} \text { applied } \\
\left(\mathrm{kg} \mathrm{ha}^{-1}\right)\end{array}$ & $\begin{array}{c}\mathrm{NUE}^{\mathbf{y}} \\
(\%)\end{array}$ & & $\begin{array}{c}\text { 2-yr N uptake } \\
\left(\mathrm{kg} \mathrm{ha}^{-1}\right)\end{array}$ & $\begin{array}{c}2-\mathrm{yr} \text { NUE } \\
(\%)\end{array}$ \\
\hline Control & - & - & - & $72.5 e$ & - \\
\hline $20 \mathrm{~kg} \mathrm{~N}$ & 20 & 78.9 & 0.2 & $88.4 d e$ & 79.2 \\
\hline $40 \mathrm{~kg} \mathrm{~N}$ & 40 & 102.1 & 12.6 & $118.4 a b c d$ & 114.7 \\
\hline $60 \mathrm{~kg} \mathrm{~N}$ & 60 & 117.7 & 4.7 & $146.0 a$ & 122.4 \\
\hline 0.5 (Early & 34 & 37.1 & 15.1 & $90.3 d e$ & 52.4 \\
\hline 1×Early & 68 & 24.1 & 11.7 & $96.8 \mathrm{cde}$ & 35.7 \\
\hline 2×Early & 136 & 24.4 & 15.9 & $127.4 a b c$ & 40.3 \\
\hline $0.5 \times$ Late & 30 & 45.9 & 21.4 & $102.1 b c d e$ & 67.9 \\
\hline $1 \times$ Late & 59 & 36.9 & 29.6 & $111.8 b c d$ & 66.6 \\
\hline $2 \times$ Late & 118 & 37.1 & 13.6 & $131.6 a b$ & 46.5 \\
\hline LSD $(0.05)$ & & $\mathrm{NS}^{\mathrm{x}}$ & NS & 33.4 & NS \\
\hline$P>F$ & & 0.1153 & 0.4963 & 0.002 & 0.3338 \\
\hline Mean & & 58 & 13.85 & 108.3 & 70.6 \\
\hline CV (\%) & & 83.26 & 126.92 & 19.9 & 79.03 \\
\hline $\begin{array}{l}\text { Contrast } \\
\text { Early vs. Late }\end{array}$ & & 0.712 & 0.0576 & 0.5299 & \\
\hline
\end{tabular}

${ }^{\mathrm{z}} 0.5 \times, 1 \times$ and $2 \times$ refer to the amount of alfalfa harvested from an area $0.5,1$ and 2 times the wheat plot area. The 20, 40, 60 kg N treatments consisted of 20 , 40 and $60 \mathrm{~kg} \mathrm{~N} \mathrm{ha}^{-1}$ applied as ammonium nitrate. Early application timing was before wheat emergence. Late application timing was at the three-leaf stage. ${ }^{\mathbf{y}_{\text {Nitrogen }}}$ use efficiency $(\mathrm{NUE})=(($ treatment $\mathrm{N}$ uptake - control $\mathrm{N}$ uptake $) / \mathrm{N}$ applied $) \times 100$.

${ }^{\mathrm{N} S}$, non-significant.

$a-e$ Means followed by the same letter within a column are not significantly different $(P>0.05)$ according to Fisher's protected LSD.

tribute to grain protein rather than other yield components (Sander et al. 1987). With high initial N availability, a higher yield potential would be set in the ammonium nitrate treatments, as is reflected by the lower crop yields in the mulch treatments. With higher yield, a dilution of nitrogen occurs among yield components and grain protein is lowered (Fowler et al. 1990).

A similar comparison was found between the $2 \times$ Early treatment and the $40 \mathrm{~kg} \mathrm{~N}$ treatment at Winnipeg 2003, where yield and $\mathrm{N}$ uptake were equivalent for the two treatments, and yet the mulch treatment resulted in higher protein concentration (Table 6).

\section{Second-year N Uptake and Yield of Oat}

Mulch-treated plots at Winnipeg were evaluated in the year after mulch application to quantify the amount of mulchsupplied $\mathrm{N}$ available to a second crop (oat). Oat grain yield and grain $\mathrm{N}$ yield was higher in the $2 \times$ mulch rates compared with the control and ammonium nitrate treatments (Table 7). This indicates that mulch-supplied $\mathrm{N}$ was the source of increased second-year oat yields in the mulched plots. Other workers have also found positive $\mathrm{N}$ uptake benefits for multiple years in crops grown after incorporation of alfalfa residues (Bullied et al. 2002).

\section{Cumulative $\mathbf{N}$ uptake}

Total $\mathrm{N}$ uptake over $2 \mathrm{yr}$ was determined for both the Winnipeg 2002 and Winnipeg 2003 site years by adding biomass N uptake for the wheat and oat crops (Tables 8 and 9). The $2 \times$ mulch rates increased 2-yr N uptake compared with the control, at both site years (Tables 8 and 9). The $1 \times$ mulch rate had a 2yr effect on N uptake only in the Winnipeg 2003 site, and the
$0.5 \times$ mulch rates had no 2-yr effect. Mulch application timing had no effect on 2-yr N uptake.

At the Winnipeg 2002 site, crops grown with the 2xEarly and $2 \times$ Late treatments took up an additional 31 and $35 \mathrm{~kg} \mathrm{~N}$ $\mathrm{ha}^{-1}$, respectively, compared with the control (Table 8), and equivalent to the $40 \mathrm{~kg} \mathrm{~N}$ treatment. Higher $\mathrm{N}$ uptake occurred at the Winnipeg 2003 site where the $2 \times$ Early and $2 \times$ Late treatments took up an additional 55 and $58 \mathrm{~kg} \mathrm{~N}$ $\mathrm{ha}^{-1}$, respectively, compared with the control (Table 9), and equivalent to the $60 \mathrm{~kg} \mathrm{~N}$ treatment.

The poor $2-\mathrm{yr} \mathrm{N}$ uptake response to the $0.5 \times$ and $1 \times$ mulch rate treatments indicates that $2 \times$ mulch rates will be required to achieve multi-year $\mathrm{N}$ uptake benefits from alfalfa mulch application. Schäfer et al. (2002) also suggested $2 \times$ mulch rates were needed to achieve N-uptake benefits, although in their study $2 \times$ rates were suggested as necessary already in the year of application, whereas in the present study $0.5 \times$ and $1 \times$ mulch rates were sufficient to achieve first-year N-uptake benefits (Table 5).

\section{Nitrogen Use Efficiency}

Two-year $\mathrm{N}$ use efficiency of the mulch treatments was between 11 and 19\% at the Winnipeg 2002 site (Table 8), and between 36 and 68\% at the Winnipeg 2003 site (Table 9.) These cumulative $\mathrm{N}$ uptake results naturally lead to the question of what happened to the remaining 32 to $89 \%$ of the $\mathrm{N}$ that was applied with the alfalfa mulch. Frequent rains following mulch application in 2002 may have promoted $\mathrm{N}$ losses through volatilization (Janzen and McGinn 1991) denitrification, and leaching (Groffman et al. 1987; Rasse et al. 1999). Nevertheless, a large portion of the original $\mathrm{N}$ likely remained in the soil in the form of stable organic compounds following the harvest of the second crop (Ladd et al. 
1985; Janzen et al. 1990). Further long-term research is needed to determine the quantities of mulch-N that become available in subsequent years.

The 2-yr $\mathrm{N}$ use efficiency of the ammonium nitrate treatments was higher than that of the mulch treatments, ranging from 90 to $122 \%$. An explanation for this observation is that the majority of the ammonium nitrate- $\mathrm{N}$ was likely already used by the wheat crop during the first cropping season (Tables 8 and 9), whereas a large portion of mulch-supplied $\mathrm{N}$ is presumed to have remained in the soil as decomposing residues with potential to supply $\mathrm{N}$ to subsequent crops (Janzen et al. 1990). Higher $\mathrm{N}$ uptake, grain yields, and grain $\mathrm{N}$ yields in the oats grown on the mulched plots further support that more $\mathrm{N}$ is supplied to the second crop from alfalfa mulch than from ammonium nitrate (Table 7).

The results of this experiment agree with the numerous studies that report on the long-term $\mathrm{N}$ benefits of incorporated alfalfa. Bullied et al. (2002) found greater grain yield, protein content, and grain $\mathrm{N}$ yield in second-crop barley grown after single-year alfalfa stands (alfalfa was seeded in spring, hayed twice during the summer and incorporated in the fall) compared with second-crop barley grown after canola or fallow controls. Long-term $\mathrm{N}$ and non- $\mathrm{N}$ benefits of alfalfa to following crops have been reported by many workers (Ladd et al. 1985; Janzen et al. 1990; Hoyt 1990; Janzen and McGinn 1991).

\section{SUMMARY AND CONCLUSIONS}

This study investigated a novel use of alfalfa in a low-input grain production system. Depending on rate of application, positive effects of alfalfa mulch to wheat included weed suppression, moisture conservation, and increased $\mathrm{N}$ uptake, yield and grain protein concentration. In general, mulch benefits increased as mulch rate increased from $0.5 \times$ to $2.0 \times$ the natural mulch rate. However, one exception was a negative effect on wheat yield observed at one site when a high rate of mulch (6.6 t ha ${ }^{-1}$ dry weight) was applied at the three-leaf stage.

Mulching at the three-leaf stage of wheat was more suppressive against weeds than mulching prior to emergence, possibly due to higher rates of application and a longer duration of weed suppression in the late applications. Low rates of mulch applied prior to wheat emergence provided the lowest weed suppression, and even appeared to stimulate growth in one instance. The timing of mulching may be influenced by weeds in the alfalfa to avoid introduction of weed seeds; Late mulching resulted in less dandelion establishment in this research. Time of application did not affect $\mathrm{N}$ uptake by wheat or following oat crops.

Two advantages of mulch over ammonium nitrate-N sources included better soil moisture conservation and higher grain protein concentration.

An estimated 11 to $68 \%$ of mulch $\mathrm{N}$ was taken up by two successive crops. The remaining $\mathrm{N}$ may be retained in plant residues or microbial biomass that may supply $\mathrm{N}$ to subsequent crops, or may have been lost due to volatilization, denitrification and leaching. Within a cropping system where alfalfa mulch was applied annually, the soil organic $\mathrm{N}$ pool and the $\mathrm{N}$ supplying ability of the soil is expected to increase over time.
In a strip farming system, $2 \times$ mulch rates achieved with a $2: 1$ planting ratio of alfalfa to annual crops on a land area basis would likely provide sufficient mulch material for moisture conservation, weed suppression, and $\mathrm{N}$ benefits in the year of application, and additional $\mathrm{N}$ benefits to crops in subsequent years. Moisture conservation, weed suppression and multi-year $\mathrm{N}$ benefits are unlikely from $0.5 \times$ and $1 \times$ mulch rates, and $0.5 \times$ mulch rates may actually stimulate weed growth. However, the $0.5 \times$ and $1 \times$ mulch rates may provide $\mathrm{N}$ benefits to crops in the year of application.

This study did not consider the dynamics of nutrients other than N. Future research should be done to determine whether alfalfa mulch applied to crops like wheat can increase availability of phosphorus and other nutrients.

In conclusion, using alfalfa as mulch on spring wheat was a successful way to extract value from alfalfa hay without feeding it to cattle, and may be an avenue for straight-grain organic farmers to increase alfalfa acreage in order to capture its soil building benefits.

Biston, R. and Clamot, G. 1982. Use of near-infrared reflectance spectroscopy and dye-binding techniques for estimating protein in oat. Cereal Chem. 59: 333-335.

Blum, U., King, L. D., Gerig, T. M., Lehman, M. E. and Worsham, A. D. 1997. Effects of clover and small grain cover crops and tillage techniques on seedling emergence of some dicotyledonous weed species. Am. J. Altern. Agric. 12: 146-161. Boyd, N. S. and Van Acker, R. C. 2003. The effects of depth and fluctuating soil moisture on the emergence of eight annual and six perennial plant species. Weed Sci. 51: 725-730.

Bullied, W. J., Entz, M. H., Smith, S. R. J. and Bamford, K. C. 2002. Grain yield and $\mathrm{N}$ benefits to sequential wheat and barley crops from single-year alfalfa, berseem and red clover, chickling vetch and lentil. Can. J. Plant Sci. 82: 53-65.

Chepil, W. S. 1946. Germination of weed seeds. Sci. Agric. 26: 307-346.

Cueto Wong, J. A., Guldan, S. J., Lindemann, W. C. and Remmenga, M. D. 2001. Nitrogen recovery from ${ }^{15} \mathrm{~N}$-labeled green manures. I. Recovery by forage sorghum and soil one season after green manure incorporation. J. Sustain. Agric. 17: 27-42.

Duley, F. L. and J. C. Russel. 1939. The use of crop residues for soil and moisture conservation. J. Am. Soc. Agron. 31: 703-709.

Entz, M. H., Baron, V. S., Carr, P. M., Meyer, D. W., Smith, S. R. J. and McCaughey, W. P. 2002. Potential of forages to diversify cropping systems in the northern Great Plains. Agron. J. 94: 240-250.

Entz, M. H., Guilford, R. and Gulden, R., 2001. Crop yield and soil nutrient status on 14 organic farms in the eastern portion of the northern Great Plains. Can. J. Plant Sci. 81: 351-354.

Fowler, D. B., Brydon, J., Darroch, B. A., Entz, M. H. and Johnston, A. M. 1990. Environment and genotype influence on grain protein concentration of wheat and rye. Agron. J. 82: 655-664.

Fribourg, H. A. and Bartholomew, W. V. 1956. Availability of nitrogen from crop residues during the first and second seasons after application. Soil Sci. Soc. Proc. 20: 505-508.

Gill, J. L. 1978. Design and analysis of experiments in the animal and medical sciences: Volume 3 Appendices. Iowa State University Press, Ames, IA.

Groffman, P. M., Hendrix, P. F. and Crossley, D. A. J. 1987. Nitrogen dynamics in conventional and no-tillage agroecosystems with inorganic fertilizer or legume nitrogen inputs. Plant Soil 97: 315-332. 
Hoyt, P. B. 1990. Residual effects of alfalfa and bromegrass cropping on yields of wheat grown for 15 subsequent years. Can. J. Soil Sci. 70: 109-113.

Janzen, H. H., Bole, J. B., Biederbeck, V. O. and Slinkard, A. E. 1990. Fate of $\mathrm{N}$ applied as green manure or ammonium fertilizer to soil subsequently cropped with spring wheat at three sites in western Canada. Can. J. Soil Sci. 70: 313-323.

Janzen, H. H. and McGinn, S. M. 1991. Volatile loss of nitrogen during decomposition of legume green manure. Soil Biol. Biochem. 23: 291-297.

Kelner, D. J., Vessey, J. K. and Entz, M. H. 1997. The nitrogen dynamics of 1-, 2- and 3-year stands of alfalfa in a cropping system. Agric. Ecosyst. Environ. 64: 1-10.

Köpke, U. 1998. Why to use the term "Organic" Agriculture? In Report of the Fourth ENOF Workshop: The Future of Organic Farming Systems. Edinburgh, Scotland, 1998 Jun. 25-26.

Ladd, J. N., Amato, M. and Oades, J. M. 1985. Decomposition of plant material in Australian soils. III. Residual organic and microbial biomass $\mathrm{C}$ and $\mathrm{N}$ from isotope-labelled legume material and soil organic matter, decomposing under field conditions. Aust. J. Soil Res. 23: 603-611.

Lafond, G. P., Boyetchko, S. M., Brandt, S. A., Clayton, G. W. and Entz, M. H. 1996. Influence of changing tillage practices on crop production. Can. J. Plant Sci. 76: 641-649.

Mahler, R. L. and Auld, D. L. 1989. Evaluation of the green manure potential of Austrian winter peas in northern Idaho. Agron. J. 81: 258-264.

Mahler, R. L. and Hemamda, H. 1993. Evaluation of the nitrogen fertilizer value of plant materials to spring wheat production. Agron. J. 85: 305-309.

Manitoba Agriculture and Food. 2001. Soil fertility guide. Revised ed. Manitoba Agriculture and Food, Winnipeg, MB.
Ominski, P. D., Entz, M. H. and Kenkel, N. 1999. Weed suppression by Medicago sativa in subsequent cereal crops: a comparative survey. Weed Sci. 47: 282-290.

Rasse, D. P., Smucker, A. J. M. and Schabenberger, O. 1999. Modifications of soil nitrogen pools in response to alfalfa root systems and shoot mulch. Agron. J. 91: 471-477.

Sander, D. H., Allaway, W. H. and Olson, R. A. 1987. Modification of nutritional quality by environment and production practices. Pages 45-82 in R. A. Olson and K. J. Frey, eds. Nutritional quality of cereal grains: Genetic and agronomic improvement. ASA, CSSA, SSSA, Madison, WI.

Schäfer, W., Väisänen, J. and Pihala, M. 2002. Technique of green mulch spreading. Agrifood Research Finland, Agriculture Engineering Research (Vakola). Vakolan tutkimusselostus. Report no. 79: 1-65.

Teasdale, J. R. 1993. Interaction of light, soil moisture, and temperature with weed suppression by hairy vetch residue. Weed Sci. 41: 46-51.

Teasdale, J. R., Beste, C. E. and Potts, W. E. 1991. Response of weed to tillage and cover crop residue. Weed Sci. 39: 195-199.

Teasdale, J. R. and Mohler, C. L. 1993. Light transmittance, soil temperature, and soil moisture under residue of hairy vetch and rye. Agron. J. 85: 673-680.

Teasdale, J. R. and Mohler, C. L. 2000. The quantitative relationship between weed emergence and the physical properties of mulches. Weed Sci. 48: 385-392.

Yunusa, I. A. M., Sedgley, R. H. and Siddique, K. M. H. 1994. Influence of mulching on the pattern of growth and water use by spring wheat and moisture storage on a fine textured soil. Plant Soil 160: 119-130. 